\title{
ITGAM wt Allele
}

National Cancer Institute

\section{Source}

National Cancer Institute. IT GAM wt Allele. NCI Thesaurus. Code C51167.

Human IT GAM wild-type allele is located in the vicinity of $16 \mathrm{p} 11.2$ and is approximately 83 $\mathrm{kb}$ in length. This allele, which encodes integrin alpha-M protein, plays a role in neutrophil and monocyte adherence to stimulated endothelium, and also in the phagocytosis of complement coated particles. 